DOI: https://doi.org/10.47405/mjssh.v6i7.867

\begin{tabular}{|c|c|}
\hline 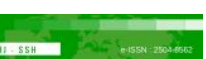 & Malaysian Journal of Social Sciences and Humanities (MJSSH) \\
\hline Malaysian Journal of & Volume 6, Issue 7, July 2021 \\
\hline (MJ - SSH) & e-ISSN : 2504-8562 \\
\hline & $\begin{array}{l}\text { Journal home page: } \\
\text { www.msocialsciences.com }\end{array}$ \\
\hline
\end{tabular}

\title{
Google Classroom as Perceived by Educators: An Overview
}

\author{
Mohamad Syafiq Ya Shak ${ }^{1}$, Mohd Haniff Mohd Tahir ${ }^{2}$, Airil Haimi Mohd Adnan ${ }^{3}$, \\ N Shushma Devi Piaralal ${ }^{4}$, Dianna Suzieanna Mohamad Shah ${ }^{1}$ \\ ${ }^{1}$ Academy of Language Studies, Universiti Teknologi MARA Perak Branch, Perak, Malaysia \\ ${ }^{2}$ Faculty of Languages and Communication, Universiti Pendidikan Sultan Idris (UPSI), Perak, Malaysia \\ ${ }^{3}$ Academy of Language Studies, Universiti Teknologi MARA Shah Alam, Malaysia \\ ${ }^{4}$ Department of English Language, Sekolah Menengah Kebangsaan Buntong, Perak, Malaysia
}

Correspondence: Mohamad Syafiq Ya Shak (moham381@uitm.edu.my)

\begin{abstract}
Learning Management System (LMS) is gaining prominence in how education is delivered today due to the increased popularity of remote and online distance learning and the unimaginable COVID-19 pandemic that stuns the world. One of the more popular LMSs in the world is Google Classroom (GC). Due to its popularity, it is essential for the perception of its users particularly educators to be gauged as it is believed that their perception could determine what they do in their teaching and learning sessions. This paper reviewed eleven selected past studies about educators' perception on the use of GC. The content of these studies was analyzed and coded into themes and specific categories by using the Atlas.ti Software. In general, educators seem to hold a positive perception on the use of GC with their students. However, some reservations about the use of GC have also been expressed. Several recommendations about how GC could be improved were also offered by the participants in the studies. The gaps in the past studies might provide some ideas on how the educators' perception of GC could be better ascertained in future.
\end{abstract}

Keywords: LMS, Google Classroom, teachers’ perception, COVID-19

\section{Introduction}

In line with the changes in how education is delivered around the world, higher educational institutions have utilized the use of online Learning Management Systems (LMSs). LMSs are tools that are employed to "deliver content and facilitate learning, particularly the primary means of online teaching and learning (Kite et al., 2020, p.183). Apart from delivering learning content, LMSs are also deemed as "a critical component of students' digital learning experiences" (Koh \& Kan, 2020, p.26) as they offer a platform for students to communicate among themselves and with their instructors, while enabling students to submit their tasks online, check for their grades and obtain feedback from their instructors, apart from downloading learning materials.

Some higher education institutions in Malaysia have developed their own LMS, for example, Universiti Teknologi MARA through its 'i-learn' and 'U-Future' platforms, Universiti Pendidikan Sultan Idris with its 'myGuru' medium, and Universiti Teknologi Petronas through its 'U-Campus" features. Some others have outsourced their LMS from established platforms such as Edmodo, Moodle, Blackboard Learn, and Google Classroom. These platforms have become the backbone of teaching and learning activities 
recently, thanks to the Covid-19 outbreak which has halted physical classroom sessions around the world. Educators are forced to familiarize themselves with these platforms to ensure a steady delivery of educational content as both their students and themselves are confined to their own home.

Google Classroom (GC) is thought to be one of the most popular LMSs in the world, having doubled its active users since the beginning of the COVID-19 pandemic in March 2020 (De Vynck \& Bergen, 2020). First introduced in 2004, it is a part of Google Apps for Education, where it enables anyone with a Google account to develop and join online learning platforms or courses (Kumar \& Barvell, 2019). It offers a virtual avenue where educators can create and post learning materials in many forms such as pictures, videos, and links, manage students' tasks and assessments, and provide feedbacks to their students. Students can also communicate with their instructors through GC. More recently, the LMS has also added a video conferencing feature, which enables live teaching and learning sessions to be conducted.

Many reasons are cited for GC's growing popularity. Among others, the platform is deemed as cost effective (Inoue \& Pengnate, 2018; Ventayen et al, 2018; Rajendram, 2019), where students for example only need to register for a Google account to start enrolling in a course through GC, without having to pay for any recurring subscription fee. In addition, GC is also quick and convenient to be used (Alim et al., 2019) as it offers easy and straightforward interface while providing a one-stop resource center for the students, which in turn helps educators to manage their classes more efficiently (Apriyanti et al., 2019; Sudarsana, et al., 2019). Moreover, GC provides flexibility to its users (Mafa, 2018), in which it is accessible anytime and anywhere through multiple forms of gadgets such as its own application in a smartphone or via its website in a personal computer with an internet access.

Additionally, GC also includes smooth integration with other Google Applications (Brown, 2018). For instance, Google Docs in GC allows students to complete their tasks on the application without having to download and re-upload it later. Educators can also directly provide the grades and feedback to their students in Google Docs. Not only that, Google Meet in GC allows classes to be conducted live and virtually through video conferencing, where the students can communicate directly with their teachers as if they are attending in-person learning in physical classes. Google Forms on the other hand enables test and quizzes to be administered easily to the students, while Google Drive provides up to 15GB of free storage for the students to keep their learning materials

As previously mentioned, GC offers various features and benefits which might compel educators to adopt it for their classes. However, at times, the decision to adopt GC might boil down to the perception of these educators about how viable GC is for their students. It is interesting to examine the reasons why teachers' perception, that comes from their "experience and personality which aid them in their profession" (Donaghue, 2003, p. 344) is essential to a teaching and learning process. This is because Pajares (1992) for instance acknowledges that their perception could be considered as their personal beliefs about the curriculum, subject they are teaching, responsibility they are holding and their views regarding the students and classroom, and this perception could become an underlying assumption for them in making decisions (Nurhayati et al., 2018) and act as a foundation for their attitudes and actions (Srakang and Jansem (2013), which ultimately guide them in deciding what should be done by them inside and outside of their classroom (Jia, 2004). These voices and insights of teachers then according to Ramazani (2012), which provide input for the "reflection and discussion circling in the areas of teaching and learning" (p. 1749), could contribute towards the betterment of education.

Multiple studies have been conducted to gauge teachers and educators' perceptions on the use of GC in their teaching and learning sessions. This paper then intends to review eleven of such studies to gain noteworthy insights and outcomes on how these educators perceive the use of GC for the last five years. It aims to answer these research questions:

i. What are the benefits of GC as perceived by the educators?

ii. What are the challenges in adopting GC as perceived by the educators?

iii. What are the recommendations to improve GC as suggested by the educators? 


\section{Methodology}

This paper reviews eleven past studies focusing on GC and its users', in this case educators, perception about it. These keywords were used in the sourcing of these past studies: Google Classroom, teachers / educators, and perception / views. Initially, the researchers intended to include 'COVID-19' as one of the keywords. However, searching that involved the keyword returned very limited results, since researches on the impact of this pandemic are still ongoing and available researches have overwhelmingly focused on students' perception in adopting GC. The past studies selection then was continued based on these criteria: (1) Studies involved teachers as the participants; (2) The participants in the studies must have experiences of adopting Google Classroom as the LMS in their teaching and learning sessions; (3) The studies must be published in a journal or conference proceeding; (4) The studies were conducted within the last five years.

The qualitative software package ATLAS.ti was used to store and perform a systematic coding of the selected past studies. ATLAS.ti is one of the common computer-assisted qualitative data analysis software that is used to assist the data analysis process. To execute this, the past studies were initially transported into ATLAS.ti. Then the data was processed by segmenting, categorizing, and annotating it within and across different documents, themes, and categories. The major themes identified from this process are the benefits of GC, the challenges in using GC, and the recommendations to improve GC. The themes were then divided into several categories, which will be discussed further in the next chapter.

\section{Result and Discussion}

Table 1 summarizes the design, participants, focus, major findings, and issue(s) raised in the selected past studies. It shows that most of the selected past studies related to the educators' perception in using GC employed qualitative methods in their design. These studies also involved educators from various levels of education from pre-service educators to those who are teaching in the elementary, secondary, and tertiary levels. Most of the selected studies gauged the educators' general perception about the use of GC, in which positive views of GC were offered by many of participants of the studies. Finally, the educators' readiness to use GC seems to be the major issue for them to adopt GC for their classes, apart from the availability of proper technological equipment and internet connection.

Table 1: Content analysis of the selected past studies

\begin{tabular}{|c|c|c|c|c|c|}
\hline Author & Design & Partici-pant & Focus & $\begin{array}{c}\text { Main } \\
\text { finding(s) }\end{array}$ & Issue(s) raised \\
\hline Iftakhar (2016) & $\begin{array}{l}\text { Qualitative } \\
\text { (structured } \\
\text { interviews; } \\
\text { observation) }\end{array}$ & $\begin{array}{l}7 \text { tertiary } \\
\text { level } \\
\text { educators }\end{array}$ & $\begin{array}{l}\text { General } \\
\text { perception on } \\
\text { the use of GC }\end{array}$ & $\begin{array}{lr}\text { GC makes } \\
\text { learning more } \\
\text { effective }\end{array}$ & $\begin{array}{l}\text { Plagiarizing is } \\
\text { rampant among } \\
\text { the students' } \\
\text { assignments }\end{array}$ \\
\hline $\begin{array}{l}\text { Azhar \& Iqbal } \\
(2018)\end{array}$ & $\begin{array}{l}\text { Qualitative } \\
\text { (semi structured } \\
\text { interviews) }\end{array}$ & $\begin{array}{l}12 \text { secondary } \\
\text { school } \\
\text { educators }\end{array}$ & $\begin{array}{l}\text { General } \\
\text { perception on } \\
\text { the use of GC }\end{array}$ & $\begin{array}{l}\text { GC is merely a } \\
\text { facilitation tool } \\
\text { that can be used } \\
\text { for document } \\
\text { management } \\
\text { and basic } \\
\text { classroom } \\
\text { management, }\end{array}$ & $\begin{array}{ll}\text { GC does not } \\
\text { provide } & \\
\text { significant } & \\
\text { impact } & \text { on } \\
\text { teaching } & \\
\text { methodology } & \end{array}$ \\
\hline $\begin{array}{l}\text { Beaumont } \\
(2018)\end{array}$ & $\begin{array}{l}\text { Qualitative } \\
\text { (Case study) }\end{array}$ & $\begin{array}{l}\text { Educators at a } \\
\text { tertiary level } \\
\text { institution }\end{array}$ & $\begin{array}{l}\text { General } \\
\text { perception on } \\
\text { the use of GC }\end{array}$ & $\begin{array}{l}\text { Educators offer } \\
\text { positive } \\
\text { feedback } \\
\text { towards the use } \\
\text { of GC }\end{array}$ & $\begin{array}{l}\text { It is difficult to } \\
\text { access learner } \\
\text { analytics }\end{array}$ \\
\hline
\end{tabular}


DOI: https://doi.org/10.47405/mjssh.v6i7.867

\begin{tabular}{|c|c|c|c|c|c|}
\hline $\begin{array}{l}\text { Fitriningtyas, } \\
\text { Umamah, \& } \\
\text { Sumardi (2019) }\end{array}$ & $\begin{array}{l}\text { Qualitative } \\
\text { (interview) }\end{array}$ & $\begin{array}{l}5 \text { secondary } \\
\text { school } \\
\text { educators }\end{array}$ & $\begin{array}{l}\text { GC as a } \\
\text { media } \\
\text { learning } \\
\text { History }\end{array}$ & $\begin{array}{l}\text { GC could help } \\
\text { in increasing } \\
\text { the quality of } \\
\text { History } \\
\text { learning }\end{array}$ & $\begin{array}{l}\text { Some educators } \\
\text { are still reluctant } \\
\text { and afraid to use } \\
\text { GC. }\end{array}$ \\
\hline $\begin{array}{l}\text { Harjanto \& } \\
\text { Sumarni (2019) }\end{array}$ & $\begin{array}{l}\text { Qualitative } \\
\text { (interview) }\end{array}$ & $\begin{array}{l}7 \text { Secondary } \\
\text { school } \\
\text { educators }\end{array}$ & $\begin{array}{l}\text { General } \\
\text { perception on } \\
\text { the use of GC }\end{array}$ & $\begin{array}{l}\text { GC is helpful in } \\
\text { conducting } \\
\text { their virtual } \\
\text { classroom }\end{array}$ & $\begin{array}{l}\text { Need more time } \\
\text { and exposure to } \\
\text { maximize the } \\
\text { features of GC }\end{array}$ \\
\hline \multirow[t]{2}{*}{$\begin{array}{l}\text { Sidhu, } \quad \text { Yean, } \\
\text { Jean, } \\
\text { Abdelhai } \\
(2019)\end{array}$} & $\begin{array}{l}\text { Mixed method: } \\
\text { Quantitative } \\
\text { (questionnaire) }\end{array}$ & $\begin{array}{l}61 \quad \text { pre- } \\
\text { service } \\
\text { educators. }\end{array}$ & $\begin{array}{l}\text { Educators' } \\
\text { knowledge } \\
\text { and } \\
\text { understandin }\end{array}$ & $\begin{array}{l}\text { Pre-service } \\
\text { educators have } \\
\text { positive } \\
\text { perception of }\end{array}$ & $\begin{array}{l}\text { Educators should } \\
\text { equip themselves } \\
\text { with knowledge } \\
\text { and }\end{array}$ \\
\hline & $\begin{array}{l}\text { Qualitative } \\
\text { (semi structured } \\
\text { interviews) }\end{array}$ & $\begin{array}{l}7 \text { pre-service } \\
\text { educators }\end{array}$ & $\begin{array}{l}g \text { on the use } \\
\text { of GC }\end{array}$ & $\begin{array}{l}\text { GC as they saw } \\
\text { its potential } \\
\text { benefits }\end{array}$ & $\begin{array}{l}\text { understanding of } \\
\text { GC }\end{array}$ \\
\hline $\begin{array}{l}\text { Kumar, } \\
\text { Bervell, Osman } \\
\text { (2020) }\end{array}$ & $\begin{array}{l}\text { Qualitative } \\
\text { (interview) }\end{array}$ & $\begin{array}{l}3 \text { Tertiary } \\
\text { level } \\
\text { educators }\end{array}$ & $\begin{array}{l}\text { General } \\
\text { perception in } \\
\text { teaching IT- } \\
\text { related } \\
\text { subjects }\end{array}$ & $\begin{array}{l}\text { Educators offer } \\
\text { positive views } \\
\text { of GC }\end{array}$ & $\begin{array}{l}\text { The safety of } \\
\text { personal data; } \\
\text { Participants' } \\
\text { authentication }\end{array}$ \\
\hline Pratiwi (2020) & $\begin{array}{l}\text { Qualitative } \\
\text { (interview) }\end{array}$ & $\begin{array}{l}4 \quad \text { Secondary } \\
\text { School } \\
\text { educators }\end{array}$ & $\begin{array}{l}\text { General } \\
\text { perception in } \\
\text { the use of } C\end{array}$ & $\begin{array}{l}\text { Educators } \\
\text { prefer to use } \\
\text { GC to organize } \\
\text { digital learning }\end{array}$ & $\begin{array}{l}\text { Teacher's } \\
\text { readiness to } \\
\text { provide good } \\
\text { technology-based }\end{array}$ \\
\hline $\begin{array}{l}\text { Rachma, } \\
\text { Nurdiana, } \\
\text { Ghofur (2020) }\end{array}$ & $\begin{array}{l}\text { Quantitative } \\
\text { (closed } \\
\text { questionnaire) }\end{array}$ & $\begin{array}{l}50 \\
\text { elementary } \\
\text { school } \\
\text { educators }\end{array}$ & $\begin{array}{l}\text { Assessing } \\
\text { learning } \\
\text { outcomes by } \\
\text { GC }\end{array}$ & $\begin{array}{l}\text { GC helps } \\
\text { educators in the } \\
\text { assessment of } \\
\text { learning } \\
\text { outcomes }\end{array}$ & $\begin{array}{l}\text { Additional } \\
\text { trainings to use } \\
\text { GC for students }\end{array}$ \\
\hline $\begin{array}{l}\text { Hussein, Ow, } \\
\text { Ibrahim, \& } \\
\text { Mahmoud } \\
(2020)\end{array}$ & $\begin{array}{l}\text { Mixed method: } \\
\text { Quantitative } \\
\text { (questionnaire) } \\
\text { Qualitative } \\
\text { (open ended } \\
\text { questions) }\end{array}$ & $\begin{array}{l}120 \text { tertiary } \\
\text { level } \\
\text { educators }\end{array}$ & $\begin{array}{l}\text { Educators' } \\
\text { intention to } \\
\text { reuse GC in } \\
\text { future after } \\
\text { using it } \\
\text { during the } \\
\text { COVID-19 } \\
\text { pandemic }\end{array}$ & $\begin{array}{l}\text { Educators' } \\
\text { satisfaction in } \\
\text { using GC } \\
\text { significantly } \\
\text { influences their } \\
\text { intention to } \\
\text { reuse GC }\end{array}$ & $\begin{array}{l}\text { Access to } \\
\text { reliable and } \\
\text { stable internet } \\
\text { services could } \\
\text { inhibit the } \\
\text { adoption of GC }\end{array}$ \\
\hline $\begin{array}{l}\text { Mohd Tahir, } \\
\text { Mohd Adnan, } \\
\text { Piaralal, } \\
\text { Mohamad } \\
\text { Shah, Ya Shak } \\
(2021)\end{array}$ & $\begin{array}{l}\text { Quantitative } \\
\text { (questionnaire) }\end{array}$ & $\begin{array}{l}103 \\
\text { secondary } \\
\text { school } \\
\text { educators }\end{array}$ & $\begin{array}{l}\text { Factors } \\
\text { influencing } \\
\text { the use of GC } \\
\text { during the } \\
\text { COVID-19 } \\
\text { pandemic }\end{array}$ & $\begin{array}{l}\text { Educators feel } \\
\text { positive about } \\
\text { the use of GC. }\end{array}$ & $\begin{array}{l}\text { Equipment and } \\
\text { connection } \\
\text { remain as the } \\
\text { main issues in } \\
\text { using GC }\end{array}$ \\
\hline
\end{tabular}

\section{Benefits of adopting GC as perceived by the educators}

There are at least six benefits of adopting GC as perceived by the educators in the selected past studies. First, most of them feel that GC is easy to use (Hussein et al., 2020). This situation could be contributed to its easy and straightforward interface (Kumar et al, 2020) which helps educators and their students to navigate through the application smoothly (Beaumont, 2018). Pratiwi (2020) meanwhile reports about its ease of access, where GC is accessible through both a smartphone and a personal computer. In addition, the signing up process is easy, as the students just need to create a Google account to be enrolled in a course in GC. Not only that, this makes the class creation and enrolment processes easier (Beaumont, 2018), where students could automatically enroll in GC through a code or an invitation link provided by the educators. Through this feature, Harjanto and Sumarni (2019) note that precious time could be saved. The time can be channeled to better prepare the educators' teaching and learning sessions. 
Second, the educators also state that GC have helped them greatly in managing their students' tasks and assignments (Azhar \& Iqbal, 2018; Kumar et al, 2018). Tasks could be created easily in GC with an automatically-set deadline. These tasks could also be completed within GC through features such as Google Docs and be sent through automatically without having to be downloaded and re-uploaded later. Rachma et al. (2020) believe that this situation will enable the educators to assess the students' learning outcomes better. Apart from that, Pratiwi (2020) mentions that materials from other sources that might help the students in completing their tasks could also be provided in GC through links, documents, images, and videos, since storage is not an issue (Harjanto \& Sumarni, 2019), thanks to features such as Google Drive. Not only that, the educators' time can be further saved in managing their classes' tasks and assessments (Harjanto \& Sumarni, 2019; Hussein et al., 2020) because posts about the tasks and other learning related materials can be re-used (Beaumont, 2018). This situation will surely provide a great relief for the educators who are teaching multiple groups of students of the same subject and who are assigned with extensive teaching hours.

Third, GC is also embraced by the educators in the past studies as it provides flexibility. GC for instance could be accessed anytime and anywhere (Hussein et al., 2020; Pratiwi, 2020; Iftakhar, 2016) as long as both the educators and the students have proper devices to access it. Classes and tasks in addition could be scheduled ahead of time (Beaumont, 2018) and this will assist both students and the educators to prepare for their lessons accordingly. These situations could prove to be vital in the COVID-19 pandemic era where remote and distance learning is taking centerstage. It could also be utilized in physical classrooms especially when in-person learning is fully reinstated. Furthermore, Iftakhar (2016) reports that the flexibility that GC offers means that the educators can still complete their syllabus and lesson plans even through national holidays and unexpected situations when schools are forced to be closed. Its flexibility also means that GC could be accessed through different kinds of operating systems (OS) and devices (Harjanto \& Sumarni, 2019) and not only limited to its own operating system which is Google Chrome OS or its own line of devices like Google Pixel phones and Google Chromebook tablets.

Fourth, many educators suggest that GC has cultivated a better interaction between the educators and their students. Interactions, mainly about what is learnt through GC, are no longer bound by time and limits (Rachma et al. 2020; Hussein et al, 2020; Azhar \& Iqbal, 2018; Iftikhar, 2016). Comments and feedbacks for instance could be provided by the educators to their students privately through GC's 'Private Comment' feature, while the students themselves can also interact with their teachers through this medium. This will help introverted students to be more involved with a lesson, where they tend to keep things to themselves during physical classes.

Fifth, collaborative learning could also be encouraged through GC (Harjanto \& Sumarni, 2019; Azhar \& Iqbal, 2018; Beaumont, 2018; Iftikhar, 2016). The students for example can work together as a group to complete a task, while the teachers can easily add other teacher(s) to be become a co-teacher for a particular GC course. This situation is vital to illustrate how important teamwork is for the students as they enter the working world later.

Lastly, it is also thought that GC could cultivate innovation and creativity among its users (Kumar et al., 2020). The students can utilize other media applications and facilities in completing their tasks (Pratiwi, 2020). They could for example include videos, audio files, and exciting graphics into their assignments. The educators can also integrate different media applications, links, and websites into their lessons, which can make the lessons more interesting (Fitriningtyas et al., 2019). This will be a big shift from the previous monotonous ways of administering tasks which rely heavily on pen and paper.

\section{Challenges in adopting GC as perceived by the educators}

The educators involved in the selected past studies have identified several challenges that they have faced in adopting GC with their classes. The challenges could be divided into two groups, which are internal and external challenges. 
Internal challenges revolve around the issues that these educators have faced in terms of the GC application itself. The first internal challenge is its interface. Even though it is deemed as easy and straightforward, Kumar et al. (2020) report that its interface is unappealing especially with regards to its design. Not only that, Hussein et al. (2020) note that its design is also inflexible. This matter seems to echo what Azhar and Iqbal (2018) have disclosed earlier on GC's lack of user-friendly interface. The students for instance will not be able to amend their submitted tasks and assignments This matter might have an impact on the users' overall experience in using GC; at times, the application's attractive and appealing design could compensate for the tedious and challenging materials and contents that a course in GC offers.

The second internal challenge deals with the safety and privacy issues of the application. GC could be prone to infringement from unrelated parties (Sidhu et al., 2019). This is because almost everyone can join a course in GC as long as they register for a Google account and obtain a GC code or an invitation link. This could lead to among others the difficulties in validating the students in a GC course (Kumar et a., 2020), where irresponsible and invalidated individuals could post harmful and disturbing materials in a GC course, such as abusive images or videos and spams or phishing links, which could have dreadful consequences on other users there. In addition, a GC course could be swarmed with a large number of students, which will inevitably lead to the inability to connect to all students simultaneously (Sidhu et al., 2019). Furthermore, the privacy issues of GC also affect the educators. They have raised concerns about the privacy of their personal data since GC is linked to their personal Gmail account (Kumar et al., 2020; Azhar \& Iqbal, 2018). This matter might result in further security breaches and exploitation of their personal data.

The third internal challenge is about its limited storage. Kumar et al. (2020) disclose that the educators feel that the 15GB storage allowance provided by GC through its Free account could be insufficient for their teaching and learning matters. This could potentially be a deciding factor in adopting GC in their lessons, since not every educational establishment has the privilege of subscribing to the Premium account for GC under Google Workspace which offers unlimited storage.

The fourth internal challenge in using GC is its lack of monitoring features. Educators for instance could not really determine the visibility of whether the students are online or not during an online learning session (Sidhu et al., 2019; Azhar \& Iqbal, 2018). A lack of monitoring features also allows the students to have the tendency to go off task during an online learning session through GC. They will be tempted to open other sources which are not related to what they are learning as their online class progresses (Harjanto \& Sumarni, 2019; Azhar \& Iqbal, 2018). Furthermore, a lack of monitoring features could also pave ways for cheating (Hussein et al., 20201) and plagiarism (Iftikhar, 2016). The students might cheat their way in completing an assessment for example, by discussing the answers with their other friends by using phone. Worse, they will copy and paste the answers to an assignment from unverified sources on the Internet and present it as their own work. This is definitely not the way to inculcate integrity and academic honesty among the students.

In addition, the unavailability of a learner analytics tool also does not help the educators to monitor their students (Beaumont, 2018) as the educators will have limited ideas on elements such as their students' signing in and out tendency, participation in online discussion in their GC course thread, and whether the students have really accessed and utilized the learning materials stored in their course's GC or not. These monitoring issues should be addressed by the developer of GC as it will greatly aid the educators to tailor their GC's approach according to their students' behavior and tendency while using GC.

On the other hand, educators have also voiced three external challenges in using GC. External challenges in this context involve the concerns that these educators have on the outside factors that could potentially affect the adoption of GC for their teaching and learning purposes. The first external challenge is the educators' readiness to adopt $\mathrm{GC}$ for their classes. There are two dimensions to this issue.

The first dimension involves the educators' readiness to use the application itself. Hussein et al. (2020) disclose that educators are concerned about their lack of experiences in using GC. This matter could be contributed to limited trainings on using GC received by these educators as reported by Sidhu et al. 
(2019) and Iftikhar (2016). To further complicate the situation, some educators have also expressed their inferiority about their own digital skills (Sanchez-Cruzado et al., 2021). This will affect their level of knowledge and confidence in using GC (Mohd Tahir et al., 2021) and ultimately, their approach in using GC. They might end up using it just as another means to send and store learning materials and tasks. Even though some educators are raving about its simplicity and ease of use, some others still need to familiarize themselves with GC's interface and features and they will certainly appreciate more exposure and hands-on experiences in using GC before they can adopt it for their classes.

The second dimension to this issue is the educators' readiness to prepare materials for their students through this application. It is reported that most of the educators in past studies on GC are not yet ready to provide good technology-based materials (Pratiwi, 2020; Azhar \& Iqbal, 2018). This could again be traced back to their low level of digital skills as indicated by Sanchez-Cruzado et al, (2021) which might make these educators more reluctant to embrace digital learning materials. Moreover, according to Hussein et al. (2020), they also have limited time to develop content that is digitally ready and suits the features of GC. These teachers might end up outsourcing learning materials from various sources on the internet, which will raise questions about the materials' credibility and reliability. It is wise to remember that "useful educational technologies will be the ones that are built on reliable content using technologies to support students in manipulating the materials and engaging with the teaching [and learning process]"(Knight, 2015, p,4).

The second external challenge is about the students' responses to the feedback that is provided through GC. Some educators in the past studies have indicated that it is difficult to get feedback from their students by using GC (Kumar et al., 2020; Azhar \& Iqbal, 2019). While it is true that these educators could leave private comments on their students' submissions and tasks through GC, getting these students to respond to these private comments could prove to be an uphill challenge (Kumar et al., 2020). The educators then will be left in the dark on whether the students have taken notes of these feedbacks or they have ignored it altogether.

The third external challenge involve the device and connection issues in using GC. Many users of GC including the educators and their students are still struggling to have proper devices and an acceptable internet connection to access GC (Mohd Haniff et al., 2021; Hussein et al., 2020). It must be admitted this is an intricate situation which involves a host of determinants such as the users' geographical location and socio-economic background, the preparedness of telecommunication providers, and the political will of a government. Nevertheless, there is an urgent need for this issue to be adequately addressed, to ensure that the potential of GC in enhancing teaching and learning could be fully optimized.

\section{Recommendations to improve GC as suggested by the educators}

The educators who involved in past studies on GC have underlined four recommendations on how GC can be improved in future. First, the educators feel that an extensive guidance on how GC can be used should be provided. Although a very useful 'Help' section is available online, it is suggested that short video tutorials on how GC can be used should also be offered to the students (Kumar et al., (2020). The use of visuals could increase their understanding of how they can maximize the use of GC instead of having to read long explanation texts in the 'Help' section. Furthermore, it is also proposed that additional virtual trainings to be offered for the users of GC by the developers of GC themselves (Rachma et al., 2020; Sidhu et al., 2019; Iftikhar, 2016).

Second, in addressing the educators' concerns about breaches in GC, it is recommended that the safety level of GC to be enhanced. Perhaps, two-level authentication should be introduced for the students to be enrolled in a GC course (Kumar et al., 2020), instead of the current enrolment method of using an invitation code or a link.

Third, additional monitoring features could also be introduced in GC. For instance, a feature that allows the educators to view their students' online status during class time (Kumar et al. 2020, Sidhu et al, 2019) should be added to the application, to ensure that the students do not go off-task during a lesson. In 
addition, plagiarism detecting tools in GC should also be extended (Iftikhar, 2016) to address the issues of academic dishonesty among the students in GC. At present, GC provides an originality checking feature for the educators. However, this feature can only be utilized to detect plagiarism for five selected assignments for each GC course, and not the whole class.

Fourth, to further encourage interaction especially between the educators and their students, it is also recommended for GC to include chat features in the application since the students prefer to chat through other social messaging services such as WhatsApp (Pratiwi, 2020). Currently, the students could communicate with the educators by replying to their teacher's private comments or replying to a thread of discussion started by their teachers in GC. A more direct and immediate means of chatting could be a welcome addition to GC, especially in ensuring that the students do not go off-task and use other social applications or sites especially on their smartphones while using GC during their class time.

\section{Conclusion}

It can be concluded from the past studies on the educators' perception of GC that they seem to perceive GC positively due to its ease of use, flexibility, and its ability to help the educators to manage their classes remotely and more efficiently, encourage creativity and innovation, nurture collaboration, and inculcate a better interaction between the educators and their students.

However, concerns remain among the educators on the use of GC for their classes especially with regards to its unappealing design and interface, limited storage capacity, and safety and privacy issues. Not only that, these educators have also voiced their apprehensions about their own readiness to use GC, their students' attentiveness as classes in GC progress, and academic dishonesty among the students. Nevertheless, these educators remain bullish about GC and its potential. After all, challenge should always be welcomed, as it helps one to grow.

Finally, the educators involved in the past studies also have highlighted several recommendations that could help GC to provide a more meaningful experience to its users, notably with regards to providing extensive guidance to use GC for its users, enhanced safety and privacy measures for student enrollment into GC, and additional monitoring and communication features in the application.

\section{Future Researches}

Future researches on Google Classroom should focus on three crucial fronts. First, a longitudinal study on whether GC has any impacts on the educators' perception on GC could be conducted. This is to analyze whether increased familiarity with the use of GC could influence their views on it or not after a period of time.

Second, an instrument in the form of a survey questionnaire should be developed exclusively for GC to gauge how the educators perceive GC with more precision. This is because several past studies in this matter utilized instruments derived from a model called 'Technology Access Model' or TAM by Davies (1989). It is thought that this model could be outdated since it was developed more than thirty years ago, and it might not necessarily reflect the current teaching and learning situations with all its predicaments.

Third, it is recommended for future researches on how the educators perceive GC to focus more on the COVID-19 pandemic crisis that the world is facing at present. This is because only two past studies by Hussein et al. (2020) and Mohd Tahir et al. (2021) that are immediately available on this matter and have focused on the impact of this pandemic on the educators' perception of GC. Such researchers are urgently relevant now to analyze how COVID-19 and other matters related to it have come into play in shaping the educators' views of GC. 


\section{References}

Alim, N., Linda, W., Gunawan, F., \& Md Saad, M.S. (2019). The effectiveness of Google Classroom as an instructional media: A case of State Islamic Institute of Kendari, Indonesia. Humanities \& Social Sciences Reviews, 7(2), 240-246. Available from https://doi.org/10.18510/hssr.2019.7227

Apriyanti, D., Syarif, H., Ramadhan, S., Zaim, M., \& Agustina, A. (2019). Technology-based Google classroom in English business writing class. In Proceedings of the Seventh International Conference on Languages and Arts (ICLA 2018), 301, 689-694. Available from https://doi.org/10.2991/icla-18.2019.113.

Azhar, K. A. \& Iqbal, N. (2018). Effectiveness of Google Classroom: Teacher's perceptions. Prizren Social Science Journal, 2(2), 52- 66.

Beaumont, K. (2018). Google Classroom: An online learning environment to support blended learning. Compass: Journal of Learning and Teaching, 11(2), 1-6.

Davis, F.D. (1989). Perceived usefulness, perceived ease of use, and user acceptance of Information technology, MIS Quarterly, 13(3), 319-340.

De Vynck, G. \& Bergen, M. (2020). Google Classroom users doubled as quarantines spread. Available from https://www.bloombergquint.com/business/google-widens-lead-in-education-market-asstudents-rush-online

Donaghue, H. (2003). An instrument to elicit teachers' beliefs and assumptions. ELT Journal, 57(4), 344-351.

Fitriningtyas, D.A., Umamah, N., \& Suamrdi (2019). Google classroom: as a media of learning history. OOP Conference Series: Earth and Environmental Science, 243, 1-18.

Harjanto, A.S. \& Sumarni, S. (2019). Teachers' experiences on the use of Google Classroom. In 3rd English Language and Literature International Conference (ELLiC) Proceedings. Available from https://jurnal.unimus.ac.id/index.php/ELLIC/article/view/4704/4231

Hussein, M.H., Ow, S.H., Ibrahim, I., \& Mahmoud, M.A. (2020). Measuring instructors continued intention to reuse Google Classroom in Iraq: a mixed method study during COVID-19. Interactive Technology and Smart Education, 17(4). Retrieved from https://doi.org/10.1108/ITSE-06-2020-0095

Iftakhar, S. (2016). Google Classroom: What works and how?. Journal of Education and Social Sciences, 3, 12-18.

Inoue, M., \& Pengnate, W. (2018, May). Belief in foreign language learning and satisfaction with using Google classroom to submit online homework of undergraduate students. In 5th International Conference on Business and Industrial Research Proceedings, 618-621.

Jia, Y. (2004) ESL teacher's perceptions and factors influencing their use of classroom-based reading assessment. Bilingual Research Journal, 29(2), pp. 459-482.

Kite, J., Schlub, T. E., Zhang, Y., Choi, S., Craske, S., \& Dickson, M. (2020). Exploring

lecturer and student perceptions and use of a learning management system in a postgraduate public health environment. E-Learning and Digital Media, 17(3), 183-198. https://doi.org/10.1177/2042753020909217

Knight, B. A. (2015). Teachers' use of textbooks in the digital age. Cogent Education, 2(1), 1-10. https://doi.org/10.1080/2331186X.2015.1015812

Koh, J.H.L. \& Kan, R.Y.P. (2020). Perceptions of learning management system quality, satisfaction, and usage: Differences among students of the arts. Australasian Journal of Educational Technology, 36(3), 26-40.

Kumar, J. A., \& Bervell, B. (2019). Google classroom for mobile learning in higher education: Modelling the initial perceptions of students. Education and Information Technologies, 24, 17931817. https://doi.org/10.1007/s10639-018-09858-z.

Kumar, J.A., Bervell, B., \& Orman, S. (2020). Google Classroom: Insights from Malaysian higher education students' and instructors' experiences. Education and Information Technologies, 25(1), 4175-4195. https://doi.org/10.1007/s10639-020-10163-x

Mafa, K.R. (2018). Capabilities of Google Classroom as a teaching and learning tool in higher education. International Journal of Science Technology \& Engineering, 5(5), 30-34.

Mohd Tahir, M.H., Mohd Adnan, A.H., Piaralal, S.D., Mohamad Shah, D.S., \& Ya Shak, M.S. (2021). Factors influencing the use of Google Classroom for lessons during COVID-19 Pandemic among secondary ESL instructors. In E-Proceedings of International Conference on Language, 
DOI: https://doi.org/10.47405/mjssh.v6i7.867

Education, Humanities, \& Social Sciences, 388-395. Available from https://iledhs2021.apbuitmck.com/e-proceedings/

Nurhayati, F. K., Tarjana, S. S., \& Hersulastuti, H. (2018) Teachers' perceptions toward the implementation of 2013 Curriculum. In Proceedings of the 2nd English Language and Literature International Conference (ELLiC), 76-87. Available from https://jurnal.unimus.ac.id/index.php/ELLIC/article/download/3487/3343

Pajares, M. F. (1992). Teachers' beliefs and educational research: Cleaning up a messy construct. Review of Educational Research, 62(3), 307-332.

Pratiwi, W.R. (2020). The practice of digital learning (D-Learning) in the study from home (SFH) Policy: Teacher's perceptions. Journal of Southwest Jiaotong University, 55(4), 1-12.

Rachma, E.A., Nurdiana, R., \& Ghofur, A. (2020). The effect of the implementation of Google Classroom digital media for the easy of teachers in assessing learning outcomes. Indonesian Journal of Social Research, 2(2), 119-125.

Rajaendram, R. (2019, June29). Google classroom gets nod. The Star. Retrieved from https://www.thestar.com.my/news/nation/2019/06/29/google-classroom-gets-nod

Ramazani, M. (2012). Teachers' perceptions of using English textbooks for Iranian technical and vocational college students. Procedia - Social and Behavioral Sciences, 70, 1748 1762

Sánchez-Cruzado, C., Santiago Campión, R., \& Sánchez-Compaña, M.T. (2021). Teacher digital literacy: The indisputable challenge after COVID-19. Sustainability, 13, 1858. https://doi.org/10.3390/su13041858

Sidhu, G.K., Yean, F.Y.L., Jean, L.H., \& Abdelhai, A.E. (2019). Knowledge and understanding of Google Classroom as a teaching and learning tool: A case study. International Journal of Advanced Science and Technology, 28(8s), 687-695.

Srakang, L. \& Jansem, A. (2014). A study of teachers' perceptions toward using English textbooks: A case study of 10th grade English teachers in Maha Sarakham province (Unpublished doctoral dissertation). Srinakharinwirot University, Thailand. Available from http://ir.swu.ac.th/jspui/bitstream/123456789/4111/2/Ladaporn_S.pdf

Sudarsana, I. K., Putra, I. B. M. A., Astawa, I. N. T., \& Yogantara, I. W. L. (2019). The use of Google classroom in the learning process. Journal of Physics: Conference Series, 1175(1). Available from https://doi.org/10.1088/1742-6596/1175/1/012165.

Ventayen, R. J.M., Estira, K. L. A., De Guzman, M. J., Cabaluna, C. M., \& Espinosa, N. N. (2018). Usability evaluation of Google Classroom: Basis for the adaptation of GSuite e-learning platform. Asia Pacific Journal of Education, Arts and Sciences, 5(51), 47-51. 